\title{
BAHAN AJAR PIDATO DALAM BUKU TEKS BAHASA SUNDA (Analisis Gradasi Materi Ajar serta Relevansinya dalam Kurikulum 2013)
}

\author{
Dwi Luqiatul Fazrini \\ SMK Singaparna Kabupaten Tasikmalaya \\ Pos-el: aspardwi@yahoo.co.id
}

\begin{abstract}
Abstrak
Penelitian mengenai "Bahan Ajar Pidato dalam Buku Teks Bahasa Sunda (Analisis Gradasi Materi Ajar serta Relevansinya dalam Kurikulum 2013)", tujuannya untuk mendeskripsikan bahan ajar pidato, gradasi bahan ajar pidato, relevansinya bahan ajar pidato dalam buku teks Pamekar Diajar Basa Sunda untuk siswa setiap jenjang pendidikan dengan Kurikulum 2013. Metode yang digunakan dalam penelitian ini adalah metode penelitian kualitatif. Sumber data dalam penelitian ini adalah buku teks bahasa sunda kurikulum 2013. Pamekar Diajar Basa Sunda yang diterbitkan pemerintah Provinsi Jawa Barat. Buku teks merupakan bagian penting dari beberapa sistem pendidikan yang mendorong untuk menjelaskan hal yang ada pada kurikulum dan menjadi buku pedoman untuk guru dalam melaksanakan kegiatan pembelajaran. Kesimpulan hasil penelitian, Bahan ajar pidato di setiap jenjang pendidikan SD kelas VI, SMP kelas VIII, SMA kelas X serta mempunyai stuktur tampilan yang berbeda. Bahan ajar pidato di SD ada sepuluh kegiatan belajar, di SMP ada lima kegiatan belajar, di SMA ada lima kegiatan belajar. Gradasi bahan ajar pidato yang ada mengenai tingkat pemahaman guru melalui angket. Hasilnya adalah $75 \%$ guru SD memahami isi bahan ajar pidato, $84 \%$ guru SMP memahami isi bahan ajar pidato, $73 \%$ guru SMA memahami isi bahan ajar pidato. Relevansi bahan ajar pidato, ada beberapa kegiatan yang tidak sesuai dengan tema dan ada beberapa KD yang tidak tersajikan dalam buku teks Pamekar Diajar Basa Sunda.
\end{abstract}

Kata Kunci: bahan ajar, pidato, buku teks, kurikulum 2013

\section{TEACHING MATERIALS OF SPEECH IN THE SUNDANESE LANGUAGE TEXTBOOK}

(Gradient Analysis of Teaching Materials and Its Relevance in the 2013 Curriculum)

\begin{abstract}
This study aimed to describe the speech teaching materials, their gradation, and their relevance in the textbook Pamekar Diajar Basa Sunda for students at every level of education. The book is based on the 2013 curriculum. The method used in this study is a qualitative research method. The data souce in this research is the Sundanese Language textbook Pamekar Taught Basa Sunda, based on 2013 curriculum, published by the Provincial Government of West Java. Textbook is an important part of education system that describe curriculum and become a guidebook for teachers in implementing the learning activities. Based on the results of research, teaching materials of speech at each education levels (the sixth grade elementary school, eighth grade of junior high school, and tenth grade of high school) have different structures. The speech teaching materials for elementary school have ten learning activities, for junior high school have five learning activities, for high school have five learning activities. Gradation of speech teaching materials about the teacher's level of understanding was performed through questionnaire. There are $75 \%$ of elementary school teachers, $84 \%$ of junior high school teachers, and $73 \%$ of high school teachers understand the content of the speech teaching materials. For the relevance of the speech teaching
\end{abstract}


materials, there are some activities that do not fit with the theme and there are some basic competencies that are not included in the textbook Pamekar Diajar Basa Sunda.

Keywords: Teaching Material, Speech, Textbook, 2013 Curriculum.

\section{PENDAHULUAN}

Bahan ajar adalah bahan yang disusun secara sistematis yang dipakai oleh guru dan siswa dalam proses pembelajaran. Bahan ajar merupakan salah satu faktor eksternal yang membantu siswa dalam meningkatkan kemampuan dan hasil belajarnya. Bahan ajar perlu dijelaskan sehingga sesuai dengan tujuan yang ingin dicapai. Pembelajaran dan buku teks merupakan dua hal yang saling melengkapi. Kegiatan belajar mengajar bisa berlangsung secara efektif apabila dilengkapi dengan sarana pembelajaran yang salah satunya adalah buku teks. Buku teks bisa dirancang serta digunakan dengan benar apabila memenuhi beberapa komponen pembelajaran. Komponen pembelajaran yang dimaksud adalah siswa, guru, materi atau bahan ajar, sajian bahan ajar dan latihan.

Buku teks yang bagus adalah buku teks yang sesuai dengan aturan kurikulum yang sedang digunakan. Selain sesuai dengan kurikulum, buku teks juga harus memperhatikan lingkungan di sekitar siswa. Peraturan menteri pendidikan nasional Republik Indonesia nomor 11 tahun 2005 pasal 1 menjelaskan bahwa buku teks pembelajaran adalah buku acuan wajib untuk digunakan di sekolah yang memuat materi pembelajaran dalam rangka peningkatan keimanan dan ketakwaan, budi pekerti dan kepribadian, penguasaan ilmu pengetahuan dan teknologi, kepekaan dan kemampuan estetis, potensi fisik dan kesehatan yang disusun berdasarkan standar nasional pendidikan.

Buku teks merupakan bagian penting dari beberapa sistem pendidikan yang mendorong untuk menjelaskan hal yang ada dalam kurikulum dan merupakan buku pegangan guru dalam melaksanakan pembelajaran. Buku teks bahasa sunda tidak banyak yang meneliti. Materi pembelajaran yang dianggap susah oleh siswa. Salah satu materi yang ada dalam buku teks bahasa sunda adalah pidato. Pidato dianggap susah oleh siswa dikarenakan menggunakan bahasa atau kata yang sopan, murwakanti dan retorika yang bagus.

Siswa di setiap jenjang pendidikan dianggap terampil dalam pidato pada saat syarat-syarat yang ada bisa terpenuhi diantaranya 1) menerangkan pokok pembicaraan, 2) tercapai atau tidaknya bahan, 3) sistematika menjelaskan bahan, 4) intonasi, 5) lafal, 6) memilih kata atau diksi, 7) terselipnya kalimah dari bahasa lain seperti bahasa Indonesia dan bahasa lainnya, 8) terselipnya kata dari dari bahasa lain seperti bahasa Indonesia dan bahasa lainnya, 9) tatakrama berbahasa, 10) volume suara, 11) sopan santun dalam berbicara, 12) kontak dengan audiens, 13) kualitas naskah, 14) jelas dalam berbicara.

Pidato ada dalam susunan materi yang harus diajarkan dalam kurikulum 2013. Pidato merupakan keterampilan bahasa lisan, pembelajaran yang aktif produktif. Disebut pembelajaran aktif produktif dikarenakan pembelajaran pidato bisa mencakup empat keterampilan berbahasa yaitu membaca, mendengarkan, menulis dan berbicara. Membaca pidato, mendengarkan jenis-jenis pidato dari berbagai media elektronik, menulis pidato, menggunakan tata tulis yang benar (;) yang akhirnya mempengaruhi pada berbicara (pidato). Siswa yang gemar membaca dan mendengarkan jenis-jenis pidato tentunya akan mempengaruhi pada kemampuan dalam memahami isi pidato dan mempengaruhi pada menulis serta berbicara (pidato).

Di setiap jenjang pendidikan, materi pidato diajarkan di kelas VI, VIII, dan X. tentunya materi ajar pidato di setiap jenjang pendidikan mempunyai urutan yang berbeda. Materi untuk siswa SD tentunya 
lebih gampang daripada siswa SMP begitupula dengan materi untuk siswa SMP lebih gampang dari siswa SMA.

Cara mengembangkan bahan ajar dalam buku teks merupakan hal yang ditunggu-tunggu sekali oleh guru sebagai bahan rujukan dalam kegiatan pembelajaran. Sudah ada beberapa buku teks bahasa sunda yang menyebar di wilayah Jawa Barat dari mulai kurikulum sebelumnya sampai kurikulum 2013. Buku teks bahasa sunda kurikulum 2013 disamakan oleh pemerintah daerah yaitu buku teks Pamekar Diajar Basa Sunda.

Berdasarkan dari uraian di atas peneliti akan membahas tentang bahan ajar pidato dalam buku teks dengan judul bahan ajar pidato dalam buku teks bahasa sunda (analisis gradasi dan relevansinya pada kurikulum 2013).

Bahan ajar memberikan pengaruh besar kepada siswa dalam memahami materi pembelajaran. Dengan adanya bahan ajar yang dibuat oleh guru memberikan kemudahan kepada guru dalam melaksanakan kegiatan pembelajaran. Adanya inisiatif guru dalam membuat bahan ajar tentunya menambah pengetahuan guru yang akhirnya bisa membangun dan mengembangkan komunikasi yang bagus selama proses pembelajaran. Apabila guru bisa menyusun bahan ajar, kegiatan pembelajaran akan lebih efektif antara guru dan siswa. Disamping itu, siswa akan merasa lebih percaya kepada guru.

Bahan ajar bisa dibangun oleh beberapa aspek seperti pengetahuan, nilai, sikap dan metode pembelajaran. Bahan ajar juga bisa jadi alat evaluasi hasil pembelajaran.

Cara menyusun bahan ajar harus memenuhi pada kompetensi inti, kompetensi dasar, indikator, materi ajar, kegiatan pembelajaran dan evaluasi, seperti gambar 2.1.

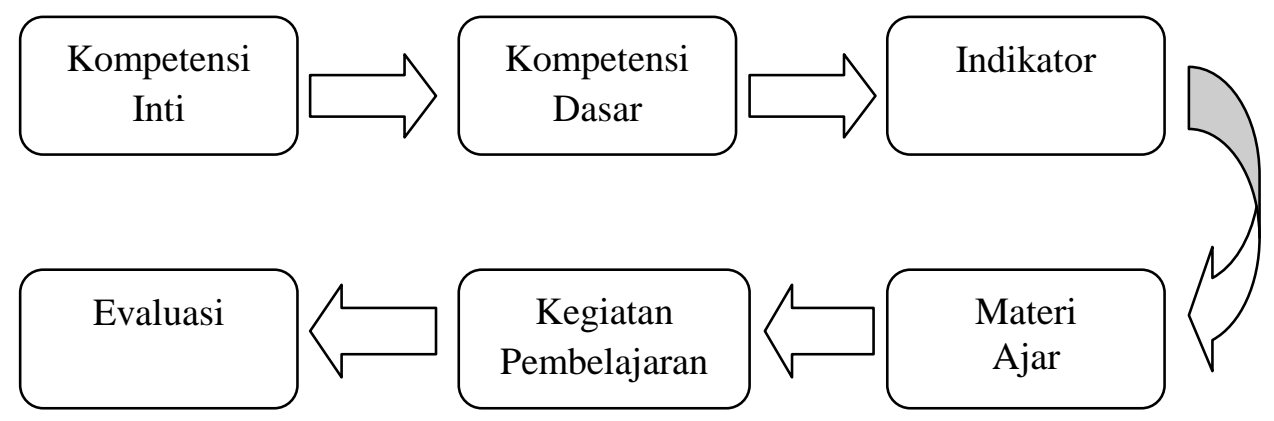

Gambar 1. Cara Menyusun Bahan Ajar

Bahan ajar harus memperhatikan hal-hal di bawah ini.

1. Susunan isi harus mengutamakan yang gampang, judul harus singkat, harus ada daftar isi, kerangka berfikirnya jelas, memenuhi prinsip bahan ajar, refleksi dan tugas.

2. Menggunakan bahasa yang mudah difahami dengan menggunakan kata dan kalimah yang jelas, keterkaitan masingmasing paragraph tidak terlalu panjang.
3. Adanya rangsangan berfikir menggunakan kalimat-kalimat yang menarik siswa untuk berfikir.

4. Memenuhi etika dan estetika dengan tidak menyalahi aturan menulis serta menarik untuk dilihat dan dibaca.

5. Materi harus instruksional yang mencakup dalam memilih teks, bahan kajian dan lembar kerja.

6. Harus menentukan materi yang akan dibuat.

7. Mengetahui sasaran pembaca. 
Hal-hal yang harus dilakukan pada saat menyusun bahan ajar yang sesuai tuntutan kompetensi yang harus tercapai oleh siswa adalah seperti di bawah ini.

\section{Analisis KIKD}

Artinya, dilakukan untuk menentukan kompetensi-kompetensi apa saja yang dibutuhkan bahan ajar. Dari hasil analisis bisa diketahui bahan ajar apa saja yang harus dipersiapkan selama satu semester.

\section{Analisis Sumber Belajar}

Artinya, adanya kesesuaian dan mudah dalam memanfaatkan dengan cara menginvetaris sumber belajar yang ada kaitannya dengan kebutuhan.
3. Memilih dan Menentukan Bahan Ajar Maksudnya, supaya memenuhi salah satu kriteria bahwa bahan ajar harus menarik untuk siswa dalam belajarnya, bisa memecahkan masalah siswa dalam mencapai kompetensi. Akhirnya bahan ajar dibuat sesuai dengan kebutuhan dan juga kesesuaian dengan KD yang akan dicapai oleh siswa.

\section{METODE}

Desain dalam penelitian ini mencakup pada langkah-langkah seperti pada gambar 2.2 .

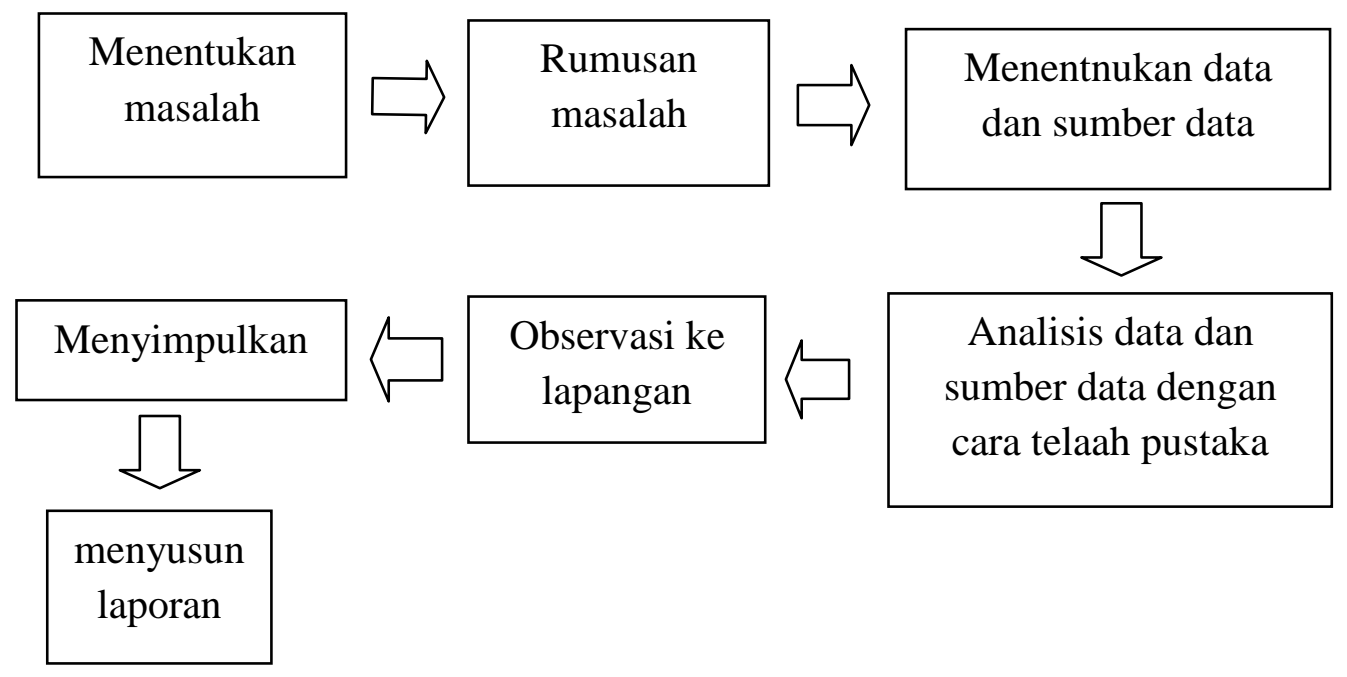

\section{Gambar 2. Desain Penelitian}

Metode yang digunakan dalam penelitian ini adalah metode penelitian kualitatif, artinya penelitian ini untuk mendeskripsikan dan menganalisis bahan ajar pidato dalam buku teks bahasa sunda. Penelitian kualitatif ini mempunyai sifat deskriptif dan eksplanatori. Artinya, penelitian ini memberikan gambaran mengenai satu hal dan memberikan jalan untuk penelitian selanjutnya. Penelitian ini memberikan eksplanasi (jelas) mengenai satu hal utamanya menurut peneliti.

Instrumen penelitian merupakan alat untuk mengumpulkan data atau cara untuk menjaring data yang diperlukan untuk menjawab pertanyaan penelitian (Arikunto, 2006, hal. 102). Adapun instrument yang diperlukan dalam penelitian ini adalah : 
1. Format Gambaran Bahan Ajar Pidato

Tabel 1: Format Gambaran Bahan Ajar Pidato

\begin{tabular}{llllcc}
\hline & 4 Keterampilan Berbahasa & Kegiatan & Hal \\
Mendengarkan & Membaca & Menulis & Berbicara & Pembelajaran & .
\end{tabular}

2. Angket

Format angket untuk guru.

\section{STUDI KETERBACAAN BAHAN AJAR PIDATO \\ DALAM BUKU TEKS PAMAGER DIAJAR BASA SUNDA PIKEUN MURID}

FORMAT JUDGEMENT GURU

\section{NAMA GURU \\ NIP/ NUPTK \\ NAMA INSTANSI \\ PENDIDIKAN}

\section{Petunjuk Pengisian}

1. Baca teks pidato dalam buku teks "Pamager Diajar Basa Sunda" dengan cermat.

2. Isilah kotak yang tersedia pada setiap pernyataan dengan :

4 = baik sekali

$3=$ baik

$2=$ cukup

$1=$ kurang

3. Isilah sesuai dengan pendapat Bapak/ Ibu tentang teks tersebut.

4. Contoh pengisian :

Kesesuaian kosa kata dalam teks dengan kosa kata siswa.

4

Kesesuaian kosa kata dalam teks dengan kosa kata siswa.

\section{HASIL DAN PEMBAHASAN}

Struktur bahan ajar pidato dalam buku teks Pamekar Diajar Bahasa Sunda ada di kelas VI, VIII, X. setelah dianalisis jumlah struktur bahan ajar pidato di setiap jenjang pendidikan berbeda. Pembelajaran di kelas VI mencakup sepuluh kegiatan belajar, di kelas VIII mencakup lima kegiatan belajar dan di kelas $\mathrm{X}$ mencakup lima kegiatan belajar. Struktur bahan ajar pidato kelas VI, terdiri dari 1) ngaregepkeun biantara, 2) ngajawab pertanyaan, 3) migawé pancén, 4) ngabédakeun biantara jeung ceramah, 5) nepikeun biantara, 6) nulis biantara, 7) ngajembaran kaweruh biantara, 8) ngahariringkeun kawih, 9) nembang jeung ngahariring, sarta 10) migawé pancén. Tema untuk bahan ajar pidato yang ada di pembelajaran 6 adalah memelihara kesehatan masyarakat. Siswa dituntut mempunyai empat keterampilan berbahasa yaitu mendengarkan, membaca, menulis dan berbicara. Kegiatan mendengarkan ada dua kali, membaca 4 kali, menulis dua kali, berbicara tiga kali.

Struktur bahan ajar pidato SMP kelas VIII sebanyak lima kegiatan belajar, diantaranya 1) Maca Biantara, 2) Nyangkem Eusi Biantara, 3) Niténan Biantara, 4) Pancén Kelompok, 5) Pancén. Siswa 
dituntut mempunyai empat keterampilan berbahasa. Kegiatan mendengarkan ada satu kali, membaca dua kali, menulis dua kali, berbicara dua kali.

Struktur bahan ajar pidato SMA kelas $\mathrm{X}$ ada lima kegiatan belajar, diantaranya 1 ) Maca Téks Biantara, 2) Nyangkem Struktur Biantara, 3) Neuleuman Padika Biantara, 4) Nganalisis Téks Biantara, 5) Nepikeun Biantara. Siswa dituntut mempunyai empat keterampilan berbahasa. Kegiatan belajar membaca ada dua kali, berbicara satu kali. Tidak ditemukan adanya kegiatan mendengarkan dan menulis. Di kelas X lebih ditekankan pada berbicara.

Gradasi bahan ajar diukur menggunakan angket. Angket ditujukan kepada guru selaku fasilitator dalam kegiatan pembelajaran. Hasil analisisnya tersajikan dalam tabel 4.1.

Tabel 2: Hasil Angket Studi Keterbacaan Guru Jenjang SD

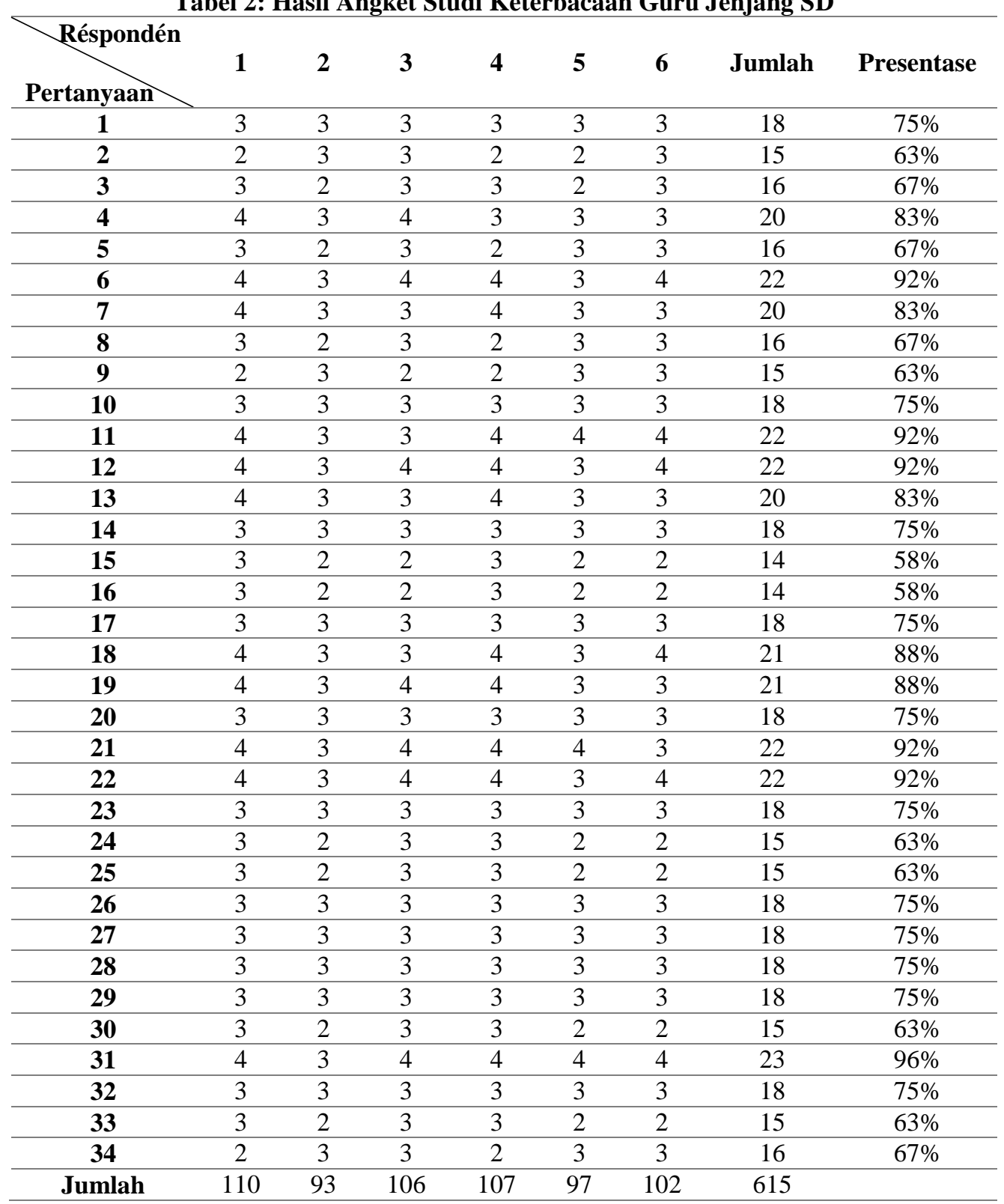

Berdasarkan tabel di atas mengenai hasil angket dengan respondennya guru SD bisa digambarkan bahwa studi keterbacaan pidato dalam buku teks Pamekar Diajar Basa Sunda untuk siswa SD kelas VI hasilnya $75 \%$ bisa dipahami. 
Tabel 3: Hasil Angket Studi Keterbacaan Guru Jenjang SMP

\begin{tabular}{|c|c|c|c|c|c|c|c|c|}
\hline $\begin{array}{l}\text { Réspondén } \\
\text { Pertanyaan }\end{array}$ & 1 & 2 & 3 & 4 & 5 & 6 & Jumlah & persentase \\
\hline (1) & (2) & (3) & (4) & (5) & (6) & (7) & (8) & (9) \\
\hline 1 & 4 & 3 & 4 & 3 & 3 & 3 & 20 & $83 \%$ \\
\hline 2 & 4 & 3 & 4 & 3 & 3 & 4 & 21 & $88 \%$ \\
\hline 3 & 3 & 3 & 3 & 3 & 3 & 3 & 18 & $75 \%$ \\
\hline 4 & 4 & 4 & 4 & 3 & 4 & 4 & 23 & $96 \%$ \\
\hline 5 & 3 & 3 & 3 & 3 & 3 & 3 & 18 & $75 \%$ \\
\hline 6 & 3 & 3 & 3 & 3 & 3 & 3 & 18 & $75 \%$ \\
\hline 7 & 3 & 4 & 4 & 3 & 3 & 4 & 21 & $88 \%$ \\
\hline 8 & 3 & 3 & 3 & 4 & 4 & 3 & 20 & $83 \%$ \\
\hline 9 & 3 & 3 & 3 & 3 & 3 & 3 & 18 & $75 \%$ \\
\hline 10 & 4 & 3 & 4 & 3 & 4 & 3 & 21 & $88 \%$ \\
\hline 11 & 3 & 3 & 3 & 3 & 3 & 3 & 18 & $75 \%$ \\
\hline 12 & 4 & 3 & 3 & 3 & 3 & 3 & 19 & $79 \%$ \\
\hline 13 & 3 & 3 & 3 & 3 & 3 & 3 & 18 & $75 \%$ \\
\hline 14 & 4 & 4 & 4 & 3 & 4 & 3 & 22 & $92 \%$ \\
\hline 15 & 3 & 4 & 4 & 3 & 4 & 4 & 22 & $92 \%$ \\
\hline 16 & 3 & 4 & 4 & 3 & 3 & 4 & 21 & $88 \%$ \\
\hline 17 & 4 & 3 & 3 & 3 & 3 & 3 & 19 & $79 \%$ \\
\hline 18 & 3 & 3 & 3 & 3 & 3 & 3 & 18 & $75 \%$ \\
\hline 19 & 3 & 3 & 3 & 3 & 3 & 3 & 18 & $75 \%$ \\
\hline 20 & 4 & 3 & 3 & 3 & 4 & 4 & 21 & $88 \%$ \\
\hline 21 & 4 & 4 & 4 & 3 & 4 & 4 & 23 & $96 \%$ \\
\hline 22 & 4 & 3 & 4 & 4 & 4 & 4 & 23 & $96 \%$ \\
\hline 23 & 4 & 3 & 3 & 3 & 3 & 3 & 19 & $79 \%$ \\
\hline 24 & 4 & 3 & 3 & 3 & 3 & 3 & 19 & $79 \%$ \\
\hline 25 & 3 & 3 & 3 & 3 & 3 & 3 & 18 & $75 \%$ \\
\hline 26 & 4 & 4 & 4 & 3 & 4 & 3 & 22 & $92 \%$ \\
\hline 27 & 4 & 4 & 4 & 3 & 3 & 4 & 22 & $92 \%$ \\
\hline 28 & 4 & 4 & 4 & 3 & 3 & 4 & 22 & $92 \%$ \\
\hline 29 & 4 & 4 & 4 & 3 & 3 & 4 & 22 & $92 \%$ \\
\hline 30 & 3 & 3 & 3 & 3 & 3 & 3 & 18 & $75 \%$ \\
\hline 31 & 3 & 3 & 3 & 3 & 3 & 3 & 18 & $75 \%$ \\
\hline 32 & 4 & 3 & 3 & 3 & 3 & 3 & 19 & $79 \%$ \\
\hline 33 & 3 & 4 & 4 & 3 & 3 & 3 & 20 & $83 \%$ \\
\hline 34 & 4 & 4 & 4 & 3 & 3 & 4 & 22 & $92 \%$ \\
\hline jumlah & 120 & 114 & 118 & 104 & 111 & 114 & 681 & \\
\hline
\end{tabular}

Berdasarkan tabel di atas mengenai hasil angket dengan respondennya guru SMP bisa digambarkan bahwa studi keterbacaan pidato dalam buku teks Pamekar Diajar Basa Sunda untuk siswa SMP kelas VIII hasilnya $84 \%$ bisa dipahami.

Tabel 4: Hasil Angket Studi Keterbacaan Guru Jenjang SMA

\begin{tabular}{ccccccccc}
\hline Réspondén & & & & & & & & \\
Pertanyaan & $\mathbf{1}$ & $\mathbf{2}$ & $\mathbf{3}$ & $\mathbf{4}$ & $\mathbf{5}$ & $\mathbf{6}$ & Jumlah & persentase \\
\hline $\mathbf{( 1 )}$ & $\mathbf{( 2 )}$ & $\mathbf{( 3 )}$ & $\mathbf{( 4 )}$ & $\mathbf{( 5 )}$ & $\mathbf{( 6 )}$ & $\mathbf{( 7 )}$ & $\mathbf{( 8 )}$ & $\mathbf{( 9 )}$ \\
\hline $\mathbf{1}$ & 3 & 4 & 3 & 3 & 4 & 3 & 20 & $83 \%$ \\
\hline $\mathbf{2}$ & 4 & 3 & 3 & 3 & 4 & 3 & 20 & $83 \%$ \\
\hline $\mathbf{3}$ & 3 & 3 & 4 & 4 & 4 & 3 & 21 & $88 \%$ \\
\hline
\end{tabular}




\begin{tabular}{|c|c|c|c|c|c|c|c|c|}
\hline 4 & 3 & 3 & 3 & 3 & 3 & 3 & 18 & $75 \%$ \\
\hline 5 & 3 & 3 & 3 & 3 & 3 & 3 & 18 & $75 \%$ \\
\hline 6 & 3 & 3 & 2 & 2 & 4 & 3 & 17 & $71 \%$ \\
\hline 7 & 2 & 3 & 3 & 3 & 3 & 3 & 17 & $71 \%$ \\
\hline 8 & 3 & 3 & 3 & 3 & 2 & 2 & 16 & $67 \%$ \\
\hline 9 & 3 & 3 & 3 & 3 & 2 & 2 & 16 & $67 \%$ \\
\hline 10 & 2 & 3 & 3 & 3 & 2 & 2 & 15 & $63 \%$ \\
\hline 11 & 4 & 4 & 4 & 4 & 4 & 4 & 24 & $100 \%$ \\
\hline 12 & 4 & 4 & 3 & 3 & 3 & 3 & 20 & $83 \%$ \\
\hline 13 & 3 & 3 & 3 & 3 & 3 & 3 & 18 & $75 \%$ \\
\hline 14 & 2 & 3 & 3 & 3 & 2 & 2 & 15 & $63 \%$ \\
\hline 15 & 1 & 3 & 4 & 4 & 1 & 1 & 14 & $58 \%$ \\
\hline 16 & 2 & 3 & 3 & 3 & 2 & 2 & 15 & $63 \%$ \\
\hline 17 & 2 & 2 & 3 & 3 & 3 & 3 & 16 & $67 \%$ \\
\hline 18 & 2 & 2 & 3 & 3 & 3 & 3 & 16 & $67 \%$ \\
\hline 19 & 3 & 3 & 3 & 3 & 3 & 3 & 18 & $75 \%$ \\
\hline 20 & 3 & 3 & 3 & 3 & 3 & 3 & 18 & $75 \%$ \\
\hline 21 & 3 & 3 & 4 & 4 & 2 & 2 & 18 & $75 \%$ \\
\hline 22 & 4 & 3 & 3 & 3 & 3 & 3 & 19 & $80 \%$ \\
\hline 23 & 2 & 2 & 3 & 3 & 3 & 3 & 16 & $67 \%$ \\
\hline 24 & 3 & 2 & 3 & 3 & 3 & 3 & 17 & $71 \%$ \\
\hline 25 & 3 & 3 & 3 & 3 & 2 & 2 & 16 & $67 \%$ \\
\hline 26 & 3 & 3 & 3 & 3 & 3 & 3 & 18 & $75 \%$ \\
\hline 27 & 3 & 3 & 3 & 3 & 2 & 2 & 16 & $67 \%$ \\
\hline 28 & 3 & 3 & 3 & 3 & 2 & 2 & 16 & $67 \%$ \\
\hline 29 & 3 & 2 & 3 & 3 & 2 & 2 & 15 & $63 \%$ \\
\hline 30 & 3 & 3 & 4 & 4 & 3 & 3 & 20 & $83 \%$ \\
\hline 31 & 3 & 2 & 4 & 4 & 2 & 2 & 17 & $71 \%$ \\
\hline 32 & 3 & 3 & 3 & 3 & 2 & 2 & 16 & $67 \%$ \\
\hline 33 & 2 & 3 & 3 & 3 & 3 & 3 & 17 & $71 \%$ \\
\hline 34 & 2 & 3 & 4 & 4 & 3 & 3 & 19 & $80 \%$ \\
\hline jumlah & 95 & 99 & 108 & 108 & 93 & 89 & 592 & \\
\hline
\end{tabular}

Berdasarkan tabel di atas mengenai hasil angket dengan respondennya guru SMA bisa digambarkan bahwa studi keterbacaan pidato dalam buku teks Pamekar Diajar Basa Sunda untuk siswa SMA kelas X hasilnya $73 \%$ bisa dipahami.
Di bawah ini disajikan tabel hasil angket studi keterbacaan bahan ajar pidato dalam buku Pamekar Diajar Basa Sunda pikeun murid SD kelas VI, SMP kelas VIII, SMA kelas X.

Tabel 5: Hasil Angket Studi Keterbacaan Bahan Ajar Pidato dalam Buku Pamekar Diajar Basa Sunda

\begin{tabular}{lccc}
\hline \multicolumn{1}{c}{ Jenjang } & SD & SMP & SMA \\
\hline Katégori & $73 \%$ & $83 \%$ & $74 \%$ \\
\hline Keterpahaman & $80 \%$ & $83 \%$ & $73 \%$ \\
\hline Kebergunaan alat bantu eksternal & $73 \%$ & $84 \%$ & $72 \%$ \\
\hline Kemenarikan & $73 \%$ & $85 \%$ & $71 \%$ \\
\hline Keseluruhan & $75 \%$ & $84 \%$ & $73 \%$ \\
\hline
\end{tabular}




\section{SIMPULAN}

Setelah dianalisis penelitian mengenai bahan ajar pidato yang ada dalam buku teks Pamekar Diajar Basa Sunda bisa disimpulkan seperti di bawah ini.

a. Bahan ajar biantara ada di setiap jenjang pendidikan yaitu SD kelas VI, SMP kelas VIII, SMA kelas X. Struktur setiap jenjang pendidikan berbeda. Di kelas VI ada sepuluh kegiatan belajar, di kelas VIII ada lima kegiatan belajar, di kelas $\mathrm{X}$ ada lima kegiatan belajar.

b. Gambaran bahan ajar di setiap jenjang atikan tidak sama. Gambaran bahan ajar di SD ada empat keterampilan berbahasa, di SMP ada empat keterampilan berbahasa, yang berbeda di SMA hanya ada dua keterampilan berbahasa yaitu membaca dan berbicara.

c. Gradasi bahan ajar pidato yaitu mengenai tingkat pemahaman guru melalui angket. Hasilnya $75 \%$ guru SD memahami isi bahan ajar pidato, 84\% guru SMP memahami isi bahan ajar pidato, $73 \%$ guru SMA memahami isi bahan ajar pidato.

d. Tingkat relevansi buku Pamekar Diajar Basa Sunda tingkat SD dan SMA hampir sama. Buku teks SMP lebih bisa diterima dan lebih dipahami dibandingkan buku teks SD dan SMA. Di tingkat SD ada tiga kegiatan belajar yang keluar dari KIKD. Di tingkat SMP ada satu kegiatan belajar yang keluar dari KIKD. Di tingkat SMA banyak sekali kekurangannya. Selain daripada kegiatan belajar yang keluar dari KIKD, ada KIKD yang tidak tersajikan yaitu KD 10.3.1 menanggapi.

\section{PUSTAKA RUJUKAN}

Arikunto. Suharsami. (2006). Prosedur Penelitian Suatu Pendekatan Praktek. Jakarta: Rineka Cipta.

Undang - Undang Republik Indonesia Nomor 11 tahun 2005 Pasal 1 tentang Buku Teks Pelajaran.

\section{UCAPAN TERIMAKASIH}

Penulis mengucapkan terima kasih kepada pemimbing tesis dalam penelitian ini. Selain itu ucapan terima kasih penulis sampaikan pula kepada ketua Podi Pendidikan Bahasa dan Budaya Sunda SPs UPI dan kepada redaksi Jurnal Lokabasa atas dimuatnya tulisan ini. 